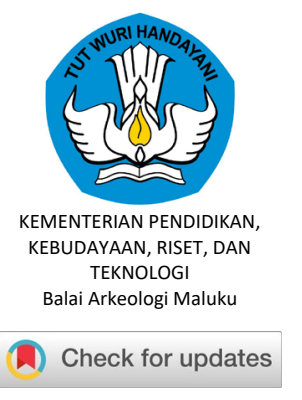

Kapata Arkeologi, 17 (1) 2021, 13-20

p-ISSN: 1858-4101, e-ISSN: 2503-0876

KAPATA ARKEOLOGI

SCIENTIFIC JOURNAL OF ARCHAEOLOGY AND CULTURAL STUDIES

Accredited by the Indonesian Ministry of Research, Technology, and Higher Education (RISTEKBRIN)
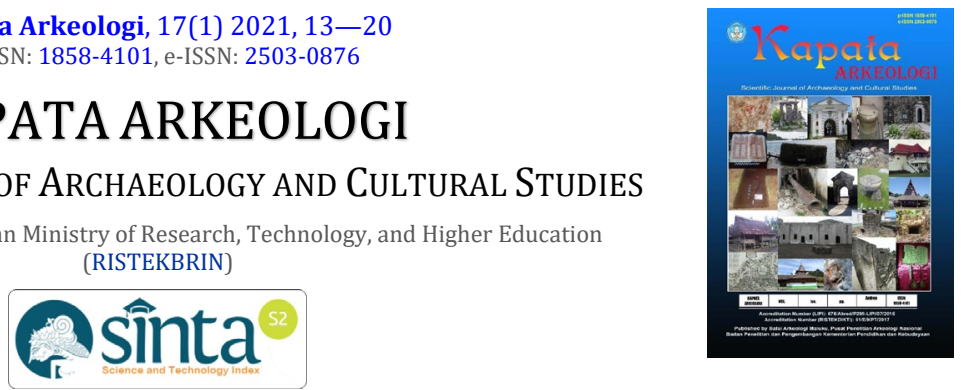

http://kapata-arkeologi.kemdikbud.go.id/

\title{
How Indonesian People in the Past Deal With Disaster MITIGATION? AN ARCHAEOLOGICAL PERSPECTIVE
}

\author{
Atina Winaya (D) 1 *, Ashar Murdihastomo (D) 2 * \\ ${ }_{1,2}$ Pusat Penelitian Arkeologi Nasional \\ J1. Condet Pejaten No.4, Jakarta Selatan 12510, Indonesia \\ *1 atina.winaya@gmail.com,*2 ashar.murdihastomo@gmail.com
}

Received: 9/07/2019; revisions: 24/09/2019 — 27/08/2020; accepted: 04/06/2021

\begin{abstract}
A natural disaster is part of our nation's journey from the prehistoric era. Even though natural disaster is an inseparable matter with Indonesian people's lives, but there is still a lack of awareness and readiness due to this issue. The high number sees it as material and non-material losses in every disaster event. This situation is caused by non-optimally disaster management implementation in Indonesia, especially in disaster mitigation. To formulate the new conception of disaster management, modern people should learn how to deal with natural disasters from ancient people. Values and local wisdom are still relevant today since we live in the same archipelago. As a science that studies extinct human culture, archaeology can help explain the history of disasters in a region and its impact on human life in the past. Using the literature study approach, this paper aims to describe disaster mitigation actions implemented by Indonesia's ancestors as a reference to disaster mitigation in modern times. At least there are two highlights of values that are still relevant. First is the mental and character building of people who live in a disaster-prone area, and second is the physical development regarding the nature of disaster in each region.
\end{abstract}

Keywords: natural disaster; disaster mitigation; ancient disaster; mitigation

\section{INTRODUCTION}

In these two decades, many natural disasters hit Indonesia, such as volcanic eruptions, earthquakes, tsunami, landslides, cyclones, and even an unpredictable land movement (liquefaction) in Palu in 2018. These various disasters happen from year to year, spread across the archipelago. This phenomenon should not be a new or strange matter for Indonesia because the geographical area is circled by the most active earthquake pathway, commonly known as the Pacific Ring of Fire, and also entangled by the number two most active earthquake pathway in the world called the Alpide Belt. That condition was exacerbated by the collision of three continents plates, i.e., Indo Australia from the south, Eurasia from the north, and the Pacific from the east. Encouraged by two extreme geophysical lines, Indonesia is home to some of the most potent natural disasters ever occurred on earth (Arif, 2011).

Indonesia has gone through various major natural disasters that have local, regional, and even global impacts from time to time. One of the extraordinary events in prehistoric times was the eruption of the ancient
Toba volcano 74.000 years ago. The mega disasteraffected climate change, ecosystem, and human populations in the prehistoric era (Noerwidi, 2012: 9-18). Entering the historical period, the most famous and perhaps the earliest recorded natural disaster was the eruption of Mount Merapi in the $10^{\text {th }}$ Century. The damage caused by the disaster resulted in the migration of the capital of the Ancient Mataram Kingdom from the central part of Java to the eastern part of Java.

In the colonial period in Indonesia, European scientists began to diligently record the natural disasters that they experienced in several regions. G.E. Rumphius, a natural scientist from Germany, recorded in his book entitled Amboina (1675) the event of a major earthquake that occurred in Ambon in 1674. The earthquake was followed by a tidal wave that hit the entire coast of Ambon Island. The northern coast on the Hitu Peninsula suffers the most damage where water rises as high as 4050 toises. The water's surface is the same as the height of a hilly peak found in coastal areas. At least more than 2.300 people were killed, including the wife and children of Rumphius (Ririmasse, 2014: 100). Not only happened in eastern Indonesia, but natural disasters have become 
common in almost all parts of the archipelago. In his book entitled Nusantara: History of Indonesia (1961), historian Bernard H.M. Vlekke noted that volcanic eruptions and earthquakes often occur in this country. One of the islands most frequently affected is Sumatra. One village was destroyed, houses collapsed, and was consumed by fire due to a massive earthquake in Mana, Bengkulu, in 1770 (Vlake, 2008).

Another major disaster that has massive global implications is the eruption of Mount Tambora on Sumbawa Island, West Nusa Tenggara. The explosion in April 1815 caused the death of no less than 71.000 people. The phenomenal impact of the events was extreme climate change, which resulted in the absence of summer in Europe that year. Drastic climate change caused massive crop failures and livestock deaths that caused the worst famine in the $19^{\text {th }}$ Century (Geria, 2015: 15). Next, the most significant catastrophic moment before entering the $20^{\text {th }}$ Century was the eruption of Mount Krakatau in the Sunda Strait in 1883. Historical sources said that the eruption was so powerful that the explosion heard up to Alice Springs in the middle of the Australian continent and islands near the African continent on the eastern part. Similar to Tambora, the Krakatau eruption also caused global climate change. The world became dark for two and a half days due to volcanic ash that filled the atmosphere with the scattering of dust reaching the skies of Norway and New York. With the explosive power of the eruption, which reached 30.000 times the atomic bomb of Hiroshima, Krakatau disaster created waves of hot clouds and tsunamis that swept away settlements on the west coast of West Java and southern part of Sumatra and claimed more than 36.000 lives (Ririmasse, 2014: 99-100). Some of the natural disasters mentioned are considered the most significant events in humanity's history, so they are recorded and documented well. Besides the megadisasters, there are also many other natural disasters with a smaller scale in various regions of Indonesia.

History has recorded various incidents of devastating natural disasters in the archipelago from time to time. However, natural disaster awareness started to emerge since the earthquake and tsunami in Aceh in 2004. The events, allegedly the most devastating natural disasters in the $21^{\text {st }}$ Century, have claimed hundreds of thousands of casualties in various regions and caused enormous material losses. Two years later, an earthquake with a large force occurred in Yogyakarta. Not only consumed nearly 5.000 fatalities, but the incidents also caused considerable damage to infrastructure. Based on many victims, both dead and missing, and the impact of severe physical damage, these two events became a lesson for the government that disaster management in Indonesia needs to be immediately designed, established, and implemented to minimize the impact of losses.
One year later, Law Number 24 the Year 2007 on Disaster Management was born, followed by Government Regulation Number 21 the Year 2008 related to the implementation of disaster management. The two legal bases guide the government in conducting disaster management in Indonesia. Disaster management contained three cycles that interrelated each other, i.e., pre-disaster, emergency response, and post-disaster (Undang-Undang RI, 2007). The pre-disaster phase covers several activities, such as prevention, mitigation, preparedness, and early warning. The emergency response phase emphasizes the response when the disasters come, and the post-disaster step includes activities such as recovery, rehabilitation, and reconstruction (Sunarti, 2014: 35). Not only does the central government on duty run it, but the local government, together with the local communities, apply the regulation to make it successful.

Even though the law and regulation have been announced and applied, the material and non-material losses at issue are still relatively high. It can be seen from the three events of natural disasters that occurred recently in 2018, i.e., earthquake in Lombok; earthquake-tsunami- liquefaction in Palu; and earthquake-tsunami in the Sunda Strait. Among these three events, the natural disasters in Palu caused the most considerable risk, coupled with the phenomenon of liquefaction, which shocked the public, so they were not ready to face it. It seems that the application of disaster management in Indonesia is not too optimal. Nevertheless, the establishment of regulations, provision, and development related to the facilities and the institution was appreciated much. The National Disaster Management Agency (Badan Penanggulangan Bencana Nasional/BPNB) was established in 2008 as a form of government performance that has been more vigilant in addressing the events of natural disasters in Indonesia.

Based on the experience of developed countries that also troubled natural disasters, such as Japan and Taiwan, disaster mitigation - which is a part of disaster management - is a critical primary step to minimize the negative impacts caused. Disaster mitigation is an aid to reduce disaster risk, both through physical development and awareness of a person/community (enhancing abilities) to face disaster challenges. As with disasters, there are potential losses in the form of death, injury, illness, life-threatening, insecurity, damage and loss of property, and social activities disturb. Mitigation activities can be carried out through disaster socialization, disaster evacuation simulations, hazardous disaster signs production, evacuation routes construction, education, and training as well (Sunarti, 2014: 34-35).

Mitigation is taken (usually in the form of specific programs) to reduce the effects of a disaster on a nation or community. For instance, developing and applying 
building codes can reduce damage and loss in the events of a disaster such as earthquakes and cyclones (Carter, 2008: 29). The term mitigation implies that while it may prevent some disaster effects, other effects will persist but can be modified or reduced if appropriate action is taken. The following activities or programs are generally regarded as coming under the mitigation:

a. enforcement of building codes

b. land-use regulations

c. safety regulations relating to a high-rise building, control of hazardous substances, etcetera

d. safety codes governing the land, sea, and air transport systems

e. agricultural programs aimed at reducing the effects of hazards in crops

f. system to protect critical installations such as power supplies and vital communications

g. development in infrastructure, such as routing a new highway (Carter, 2008: 53).

The application of disaster mitigation actions needs to be adjusted to the characteristic of each region, also in Indonesia. One region's character will undoubtedly be different from other regions so that the implementation of mitigation actions cannot be generalized. Although today the use of sophisticated technology has begun to attempt to detect the arrival of disasters and mitigation actions, there is another alternative way to improve these mitigation efforts - the alternative method, namely the study of local wisdom related to disaster issues in each region of Indonesia.

Stories about natural disaster events in the past are often tucked away in traditional song lyrics or poems, as well as fairy tales or myths that were delivered verbally to generations. There were many messages about the history of the disaster stored in it. Unlike the Europeans who wrote the catastrophic events experienced, the Indonesian ancestors prefer to speak because of the community's strong oral tradition. Although there were a few writings poured into ancient inscriptions and manuscripts. Local wisdom is contained in oral and written traditions and material culture produced by people in the past. For example, ancient buildings were built using knowledge about 'anti-earthquake' technology and construction to minimize disaster damage.

This paper tries to convey ideas that can be used to prepare the new concept of disaster management in Indonesia, especially at the stage of disaster mitigation based on an archaeological perspective. As a science that studies extinct human culture, archaeology can help explain the history of disasters in a region and its impact on human life in the past. The catastrophes that often happened at that time made our ancestors creative and innovative in creating disaster mitigation that was considered advanced in their time. The concept they used can be applied as a reference for disaster mitigation in modern times since the value is still relevant.

\section{Methods}

This study uses a literature study approach. The various kinds of literature containing previous research on disaster mitigation in the past are used as examples to provide a general description of ancient people's awareness of natural disasters. Values relevant to the current situation can be recommended to be included in the new concept of disaster mitigation, both locally and nationally. Indeed, the values can be modified according to the needs in modern times.

\section{RESULT AND DISCUSSION}

Indonesia is a country that is blessed with various values of local wisdom that rise and develop in people's daily lives. Each region has its local wisdom, formed for ages, influenced by its culture and environment. Local wisdom is the result of cultural adaptation to the surrounding environment. Even on the issue of disaster, Indonesian people nowadays can learn lessons from these traditional values. Local wisdom related to disaster mitigation has existed centuries ago since the emergence of civilization in Indonesia. Some of which are known through archaeological data will be discussed as follows.

\section{The Building Construction of Candi}

Candi is a temple building in Indonesia built during the $5^{\text {th }}$ to $15^{\text {th }}$ Centuries. Most candi found in Java is an architectural masterpiece created by Indonesia's ancestors that can still be observed until now. The magnificent building, representing Mount Mahameru, is a sacred place of worship for the gods in Hindu and Buddha religions. It is made of andesite stone in various sizes, on average $50 \mathrm{~cm}$ long, $40 \mathrm{~cm}$ wide, and $30 \mathrm{~cm}$ thick. These stones arranged with an average height of 20-30 meters will provide enough heavy power (Subagjo, 2012: 222). This has become very vulnerable in areas that have the potential for earthquakes. One of the best examples is in Yogyakarta, especially in the Prambanan area.

Yogyakarta is an area that is often hit by an earthquake because the geographical condition has four earthquake faults. One of the faults is in the Prambanan region to the southeast. Even though people realized that they were living in a potential disaster location, they continued to build candi buildings. They created a compound of candi in Prambanan; some of them were massive structures. Apparently, people in Prambanan already thought about the damage possibly caused by the earthquake. They have a way to anticipate it; in modern times, it is called disaster mitigation. 
The technique of disaster mitigation is by designing the building in such a way as 'anti-earthquake' construction. In general, there are two defining constructions, i.e., the foundation and the stone joint. The foundation or base of the structure is one of the essential components that aim to maintain the building to stand firm following its shape. In candi buildings, the foundation size is adjusted to the size of the whole building. The depth of the foundation can range from $2-$ 2,5 meters in width, according to the diagram of the structure. The foundation is made of three main components, i.e., bolder rock, gravel, mixed with sand (Balai Pelestarian Cagar Budaya Jawa Tengah, 2017). Those three components are a good combination in reducing earthquake damage because of their dynamic nature following earthquake vibrations. The other significant construction is the stone joint (stone locking technique). Like a puzzle, the technique is a unique component of construction that made the buildings standstill in an earthquake situation. Stone locking is a system of hooks between stones that make the composition of the stone will not break down or separated from its position. According to their size, location, and function, there are several types of stone joints. Some examples are as follows:

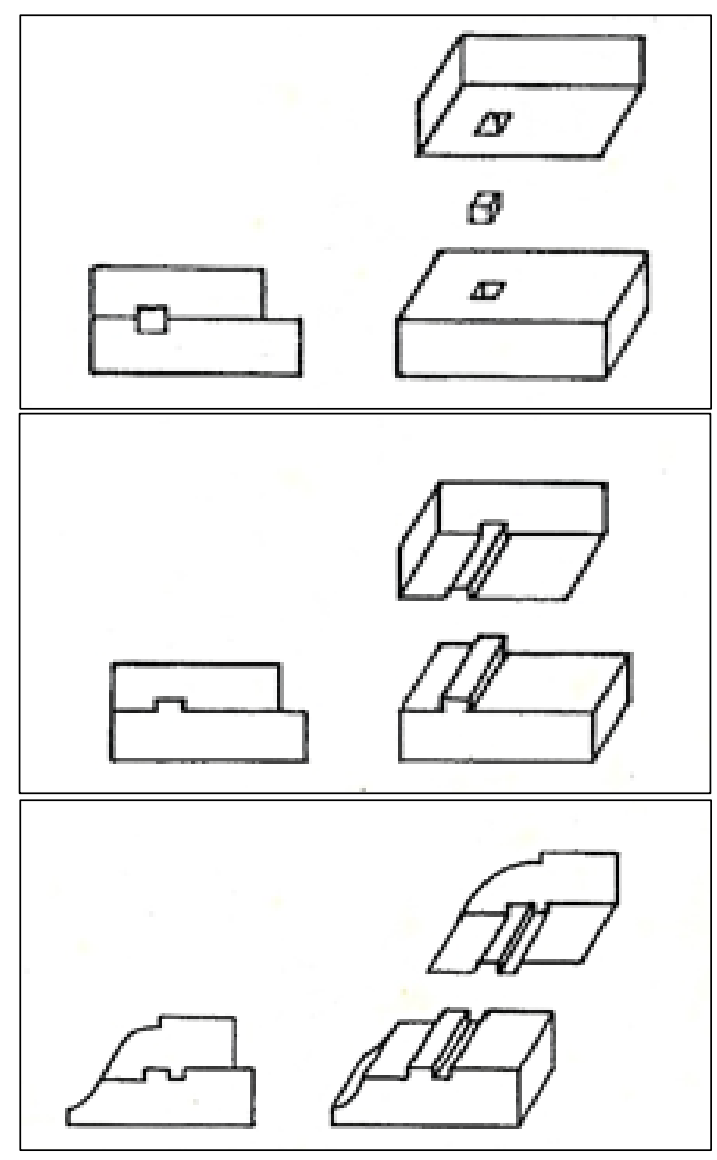

Figure 1. Various stone joints/stone locking techniques in candi buildings

(Source: Anom, 1997)
Unlike the construction of the building in modern times that use cement to attach stone components, candi uses a variety of stone locking systems to bond each of the stones. The intricate design turned out to be effective in resisting a crushing earthquake. If an earthquake occurs, the building will not immediately collapse scattered, but the stones also vibrate in its place following the earthquake rhythm. Thus, damage to candi buildings can be adequately minimized.

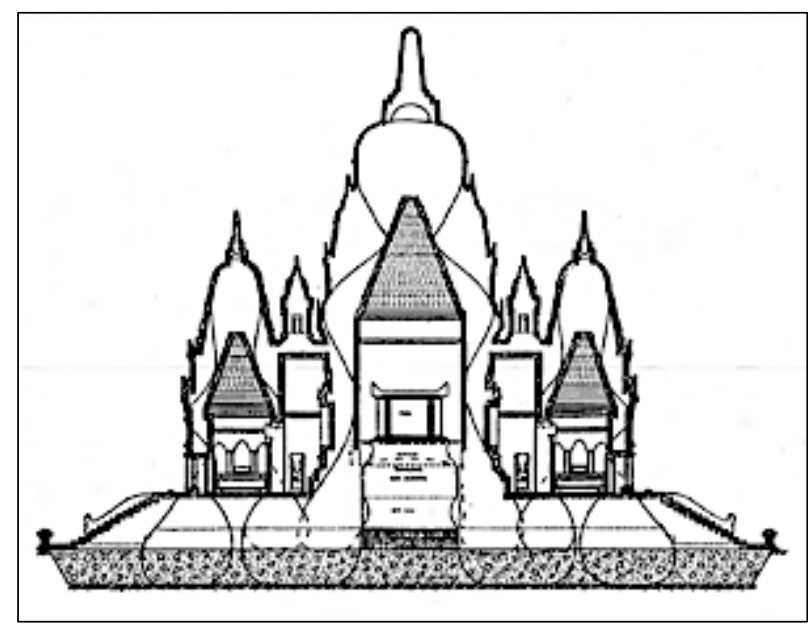

Figure 2. The flow of power in candi buildings (Source: Anom, 1997)

Another interesting technique was found in the results of doctoral research entitled Keterpaduan Aspek Teknis dan Aspek Keagamaan dalam Pendirian Candi Periode Jawa Tengah: Studi Kasus Candi Utama Sewu, conducted by Anom (1997). He found that every temple stone joint has different functions and placements. The difference is believed due to the flexural strength of a candi building (stone deformation power) (Anom, 1997). The flow of power can be seen in Figure 3.

Although the flow of strength in Figure 2 was studied in the present, what is interesting is that ancient people have succeeded in creating such a building with an 'antiearthquake' construction. The buildings allow 'flexibility' that can withstand earthquakes. As the lowest part of the entire building, the base structure is the support of the weight of all the parts above. Some of the building load is continued downward supported by the foundation and to the side supported by the outer stones arrangements. The part that holds the load, such as the door and the connection between the roof and the body, is made of good quality stone. The roof constructions strengthen with various types of unique connections on the outer stones. By this connection technique, the roof section becomes more durable and elastic (Anom \& Hatmadi, 1992: 76-78).

Knowledge of mitigation disasters, implemented by creating a complex construction building that can withstand earthquakes, shows that our ancestors were very serious about natural disasters. They exert all of 
their abilities to think, plan, and act in an attempt to minimize the damage caused by the disaster.

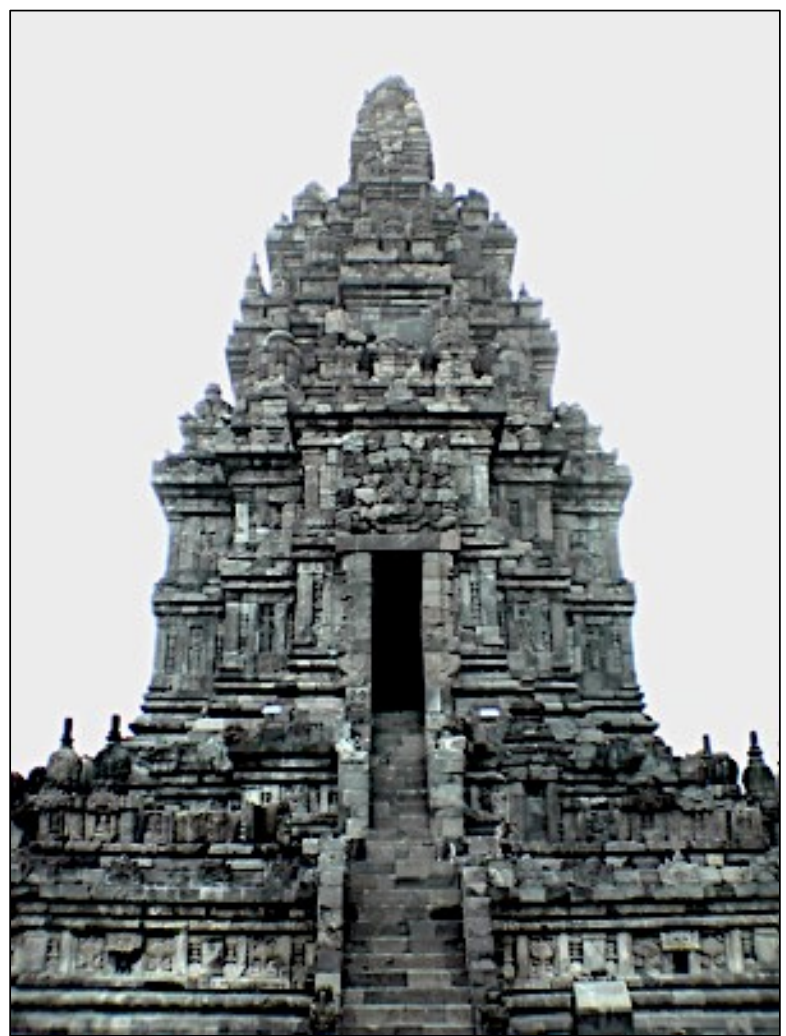

Figure 3. One of the temples at Candi Prambanan, still erect with minor damage, after the 6.4 magnitude earthquake in the year of 2006

(Source: Author Documentation, 2007)

\section{Retaining wall/talud}

Retaining wall - or in the local term called talud - is one of the environmental adaptions often found in the settlement area. Talud has functions to increase the stability level of soil, hold the land located behind it, and prevent landslides. It is frequently found in areas with unstable soil conditions.

Talud has been applied in the settlement area since the past, at least one of which was found in the Liangan site, located in Temanggung, Central Java. The site inhabited in the $6^{\text {th }}$ to $10^{\text {th }}$ Centuries is a combination of residential, religious, agricultural, and workshop places (Riyanto, 2015: 33). The study on the site landscape shows that Liangan is an area located at the foot of Mount Sindoro, which has a slope of $12-15 \%$ and wavy relief. Besides, there is a geomorphic process, such as erosion caused by water (rain and river flow). Erosion that occurs can trigger the occurrence of the landslide. This environmental condition has a negative impact on Liangan because located close to the hillside (Waliono et al., 2015).

Liangan's people attempt to cope with natural disasters by making a talud. There are two types of talud, i.e., talud made from bolder stones and talud made from tuff square stones. The wall is built with a height of about
2 meters and has a slope of $7 \%$. In addition to tackling landslides, talud is being built to anticipate the cold lava flow near the site.

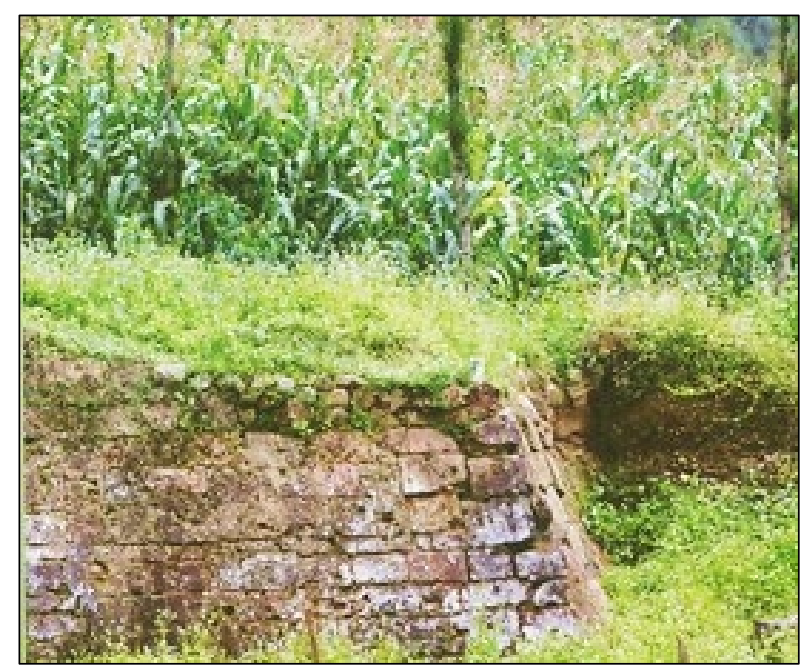

Figure 4. Talud made from tuff square stones (Source: Riyanto, 2018)

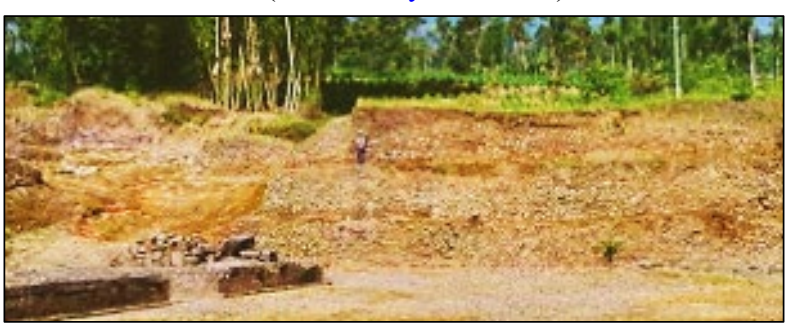

Figure 5. Talud made from bolder stones (Source: Riyanto, 2018)

\section{Canals System and Reservoirs}

The canal is an artificial waterway system constructed for various purposes of human life. Evidently, a well-managed canals system has been applied since the $14^{\text {th }}$ Century in east Java, established by the ruler of Majapahit Kingdom. In her research using aerial photographs, Karina Arifin (1983) found that the ancient canals and reservoir connected crossed all over the Trowulan city, which is believed to be the capital city of Majapahit Kingdom. The city had an area of approximately $9 \times 11 \mathrm{~km}$.

The various assumptions have been stated regarding the existence of canals in Trowulan. An opinion said the canal is used as a water transportation way. This assumption is supported by information from the foreign manuscript, which stated that the trade commodities were delivered by small boat to the kingdom's capital city (Inajati, 2014: 48). Another assumption said that the flood often hits the Trowulan area. Canals were created to break the water flow to quickly recede (Yuwono, 2013). Geographically, Trowulan is located on an alluvial fan span so that the surrounding rivers quickly silt. This acceleration of siltation directly impacts the lower capacity of the river, so the potential of water overflows is very high during the rainy season (Arifin, 1983). 
Even though it has fertile land for agriculture, Trowulan's environment also threatens natural disasters such as floods and volcanic eruptions. Majapahit people were vigilant with that situation. They were concerned about mitigation disaster issues by building reservoirs or dams in addition to canals. Ancient reservoirs are often found in the southeast of Trowulan. Based on its function, the reservoir is divided into two groups, i.e., the northwest and the eastern groups. The northwest reservoir functions as a water transportation route, while the eastern reservoir stabilizes water flow to anticipate the flood during the rainy season and drought during the dry season (Arifin, 1983).

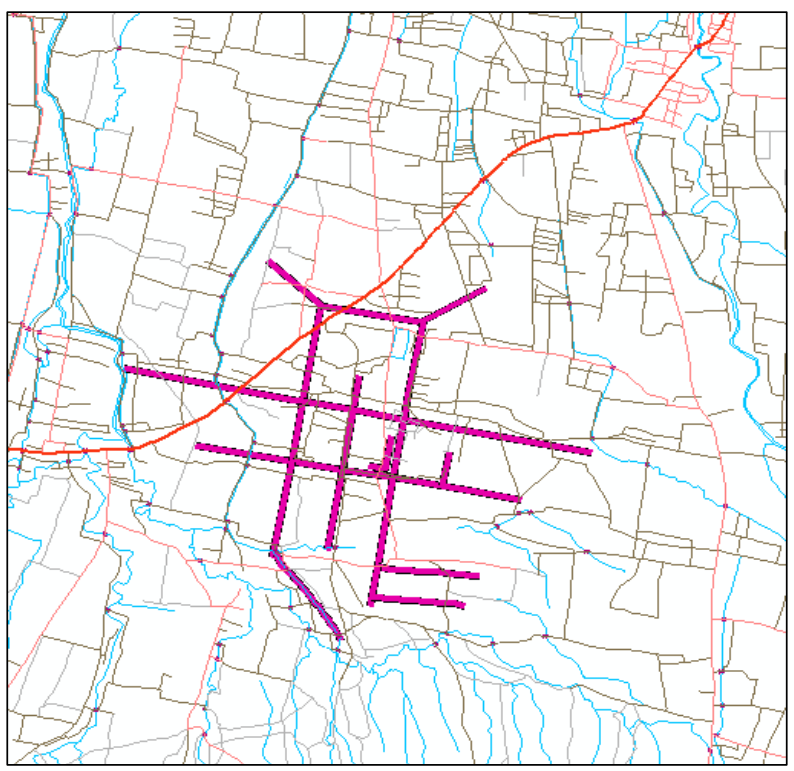

Figure 6. The canals system in Trowulan (Source: Subagio \& Poniman, 2010)

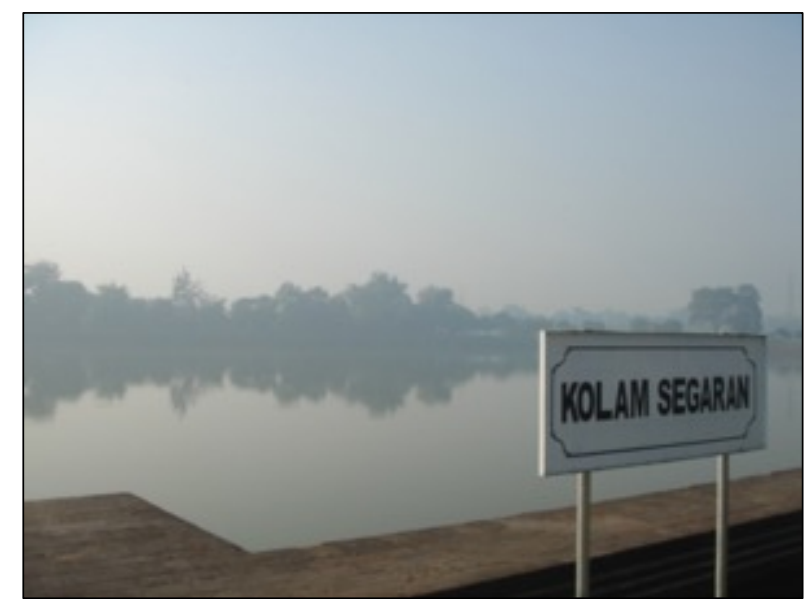

Figure 7. Segaran reservoir in Trowulan (Source: Author Documentation, 2018)

\section{Stilt Houses}

In Indonesia, many traditional communities live in a stilt houses made from wooden material. The stilt house is a house that has a particular architecture raised by pillars over the land or water surface. Such construction has many functions, i.e., to prevent natural disasters such as floods and earthquakes, to protect from wild animals, and to be used as storage or workspace (the shady space under the house). The stilt house is common local wisdom that easily found spread the archipelago because its functions are similar in one region to another. However, each area has its specific architecture following the culture they developed.

The house is usually made from local wood that was brought from its surrounding environment. From its multi-function purposes, the essential function is to survive from natural disasters. The construction of the building is considered as an 'anti-earthquake' because it has several qualifications such as simple and symmetric building's form; symmetric placement of insulating walls, doors, and windows with the building's axis; light roof materials; and stable building's foundation on the dry ground. The foundation of the houses usually uses stone pedestals (umpak) to support the pillars that lift the body of the house. The stone pedestals are not embedded in the ground. This construction made the house more resistant to the earthquake vibration and also gave the small impact of the damage.

In 2011, research on Tambora settlements showed that the houses have several different sizes. The pattern of rooms division can be known from the identification of artifacts found inside the houses (terrace, bedroom, and kitchen) (Geria, 2015: 50). The architecture of the houses is similar to the Dompu and Sumbawa's traditional stilt houses. The material uses local natural resources, such as wall and floors made from wood; and roofs made from wood, bamboo, and weeds (Raba, 2002: 63).

The descriptions above presented the actions of disaster mitigation applied by Indonesia's ancestors in the past. They realized living in a disaster area, and ancient people carried through mitigation disasters to reduce material and non-material losses. They built the physical infrastructure, following the character of the disaster they faced. This physical development also proves that ancient people had a severe awareness of natural disasters. These values should be adopted by the Indonesian people today. People must be fully aware they live in a disaster-prone area, so they should be wellprepared when the disaster happens.

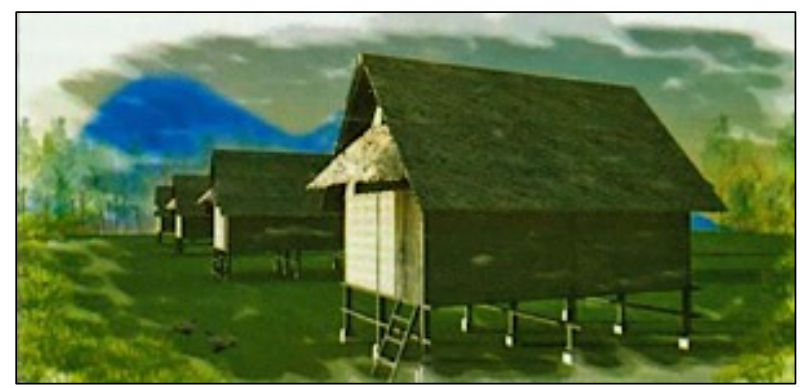

Figure 8. The reconstruction of Traditional Tambora Houses

(Source: Geria, 2015: 51) 


\section{CONCLUSION}

The experience of people in the past should be our lesson learned nowadays. At least there are two essential things regarding ancient disaster mitigation that are still relevant in modern times. First is the mental and character building of people who live in a disaster-prone area. The local community should realize and consider potential natural disasters in their region and how to deal with it (disaster mitigation). It could be one region that has more than one type of disaster, such as an earthquake along with tsunami, earthquake along with liquefaction, a flood along with landslide, and others. The central government, the local government, together with the community should gain more information and knowledge regarding the situation so they can make the proper emergency response. Several examples of response actions are providing 'the go-bag,' which is filled with a disaster supplies kit that is easy to pick when disaster comes, protecting themself to safe places, and going to gathering points or evacuation buildings/routes. Thus, if people are aware and know about things to do when the disaster occurs, they can control themselves, not panic, and take the right actions to save their lives.

Second is the physical development regarding the mitigation disaster in each region in Indonesia. The construction of buildings or infrastructures should be designed in accordance with the character of disaster in each region. Our ancestors were so concerned about this issue, such as creating an 'anti-earthquake' technology of building construction, creating complicated canals system, and so on. Although physical development is a work of the central and local government, both contractors and communities must apply the regulations and policies properly. The regulations and policies must be strictly implemented in order to reduce risks and losses caused by the disaster. Several examples are the regulation of construction of houses, office buildings, hospitals, schools, and also gathering points and evacuation buildings/routes in every neighborhood. It should be built with a standard of 'anti-disaster' construction. Also, the local government, together with its community concerned about urban planning following the character of disaster in their region.

The mental/character building and physical development regarded to disaster mitigation have been implemented in Indonesia since centuries ago, but unfortunately, the culture has not continued in modern times. This situation may occur due to the duration of colonialism in Indonesia that took almost three centuries, which caused damages in cultural order within the society. However, this condition does not to be regretted. It is time for the Indonesian people to rise and be optimistic in re-applying the culture of awareness of disasters. Many lessons were learned from our ancestor's experiences related to disaster mitigation. In addition to the lesson on the mitigation actions, the other lesson that is no less important is the dynamic of disaster history in the archipelago. Natural disasters are not a new thing to this country, and it happened since centuries ago spread across the regions. The history of disasters can explain the character of the disaster in each region so that the mitigation actions can be adequately prepared.

The new concept of disaster management is expected to involve the participation of social sciences with humanities approaches, such as archaeology, anthropology, and history. These sciences can help to reveal the history of disasters in regions and how people deal with it at the time (disaster mitigation). Each region will show different results depending on its geographical situation. This kind of study could be an input for the regulations and policies of disaster mitigation applied by the local government following the character of each region.

In the end, the Indonesian people today urgently need to realize and aware that living in disaster-prone areas should be prepared with knowledge on disaster issues, at least on disaster mitigation. A natural disaster is a part of our nation's journey. Archaeological data and historical records have proven that our ancestors have been able to apply the concept of disaster mitigation as an effort to minimize disaster impacts. Disaster mitigation in modern times could be reviewed with archaeological perspectives or any other social sciences. The combination of local wisdom knowledge and sophisticated technology will be able to bring a new concept of disaster management that can be implemented more appropriately in order for people's prosperity.

\section{ACKNOWLEDGEMENT}

The authors would like to express gratitude to all parties who supported the writing of this article. Hopefully, this could be a small trigger for the planning of a policy brief in disaster management - especially disaster mitigation - based on archaeological/historical record. 


\section{REFERENCES}

Anom, I. G. N. (1997). Keterpaduan Teknis dan Aspek Keagamaan Dalam Pendirian Candi Periode Jawa Tengah. Doctoral Thesis Universitas Gadjah Mada.

Anom, I. G. N., \& Hatmadi, T. (1992). Candi Sewu: Sejarah dan Pemugarannya. Klaten: Bagian Proyek Pelestarian/Pemanfaatan Peninggalan Serah dan Purbakala Jawa Tengah.

Arif, A. (2011). Hidup-Mati di Negeri Cincin Api. Retrieved May 15, 2019, from Kompas.com website: https://nasional.kompas.com/ $\mathrm{read} / 2011 / 09 / 14 / 05272934 /$ hidupmati.di.negeri.cincin.api?page $=$ all

Arifin, K. (1983). Waduk dan Kanal di Pusat Kerajaan Majapahit, Trowulan, Jawa Timur. Undergraduate Thesis Universitas Indonesia.

BPCB Jawa Tengah. (2017). Tahapan Mendirikan Sebuah Candi pada Masa Lalu. Retrieved June 2, 2019, from Direktorat Jenderal Kebudayaan website: https://kebudayaan.kemdikbud.go.id/bpcbjateng/tahapa n-mendirikan-sebuah-candi/

Carter, W. N. (2008). Disaster Management: A Disaster Manager's Handbook. Manila: Asian Development Bank.

Geria, I. M. (2015). Menyingkap Misteri Terkuburnya Peradaban Tambora. Yogyakarta: Gadjah Mada University Press.

Inajati, A. (2014). Majapahit: Batas Kota dan Jejak Kejayaan di Luar Kota. Yogyakarta: Kepel Press.

Noerwidi, S. (2012). Younger Toba Tephra 74 Kya: Impact on Regional Climate, Terrestrial, Ecosystem, and Prehistoric Human Population. Amerta, 30(1).

Raba, M. (2002). Dompu Dulu, Kini dan Esok. Dompu: Pemerintah Kabupaten Dompu.

Riyanto, S. (2015). Situs Liangan: Ragam Data, Kronologi, dan Aspek Keruangan. Berkala Arkeologi, 35(1).

Riyanto, S. (2018). Liyangan: Kini, Doeloe, dan Esok (a photobook). Yogyakarta: Balai Arkeologi Daerah Istimewa Yogyakarta.

Subagio, H., \& Poniman, A. (2010). Pemanfaatan GIS untuk Rekonstruksi Kawasan Strategis Nasional Trowulan. Globe, 12(2).

Subagjo. (2012). Kondisi Batu Penyusun Candi Borobudur Sebelum Pemugaran ke II (1973-1983). In 100 Tahun Pasca Pemugaran Candi Borobudur, Trilogi I: Menyelamatkan Kembali Candi Borobudur. Magelang: Balai Konservasi Peninggalan Borobudur.

Sunarti, V. (2014). Peranan Pendidikan Luar Sekolah dalam Rangka Mitigasi Bencara. SPEKTRUM PLS, II(2).

Undang-Undang RI. Undang-Undang Republik Indonesia Nomor 24 tahun 2007 tentang Penanggulangan Bencana. , (2007). Indonesia.

Vlake, B. H. M. (2008). Nusantara: Sejarah Indonesia. Jakarta: Kepustakaan Populer Gramedia (KPG).

Waliono, T., Widodo, E., Fadhilah, A., Surya, A., \& Prasastiawati, D. (2015). Pengaruh Kondisi Bentang Lahan Terhadap Kehidupan Masyarakat pada Masa Lampau di Sekitar Situs Liangan, Candi Gunung Pertapaan, Candi Gunung Candi. Yogyakarta.

Yuwono, J. S. E. (2013). Menelisik Ulang Jaringan Kanal Kuna Majapahit di Trowulan. Retrieved May 13, 2019, from Geoarkeologi.blog.ugm.ac.id website: http://geoarkeologi.blog.ugm.ac.id/2013/03/03/menelisi k-ulang-jaringan-kanal-kuna-majapahit-di-trowulan-2/ 